\title{
ATTEMPTED COPULATORY BEHAVIOUR BETWEEN TWO PHYLOGENETICALLY UNRELATED ALIEN SPECIES (COYPU, MYOCASTOR COYPUS, AND POND SLIDER, TRACHEMYS SCRIPTA): FIRST EVIDENCE
}

\author{
SHORT COMMUNICATION
}

\author{
Giancarlo Grillo ${ }^{a}$, Giancarlo Sartori ${ }^{\mathrm{a}}$, Corrado Battisti ${ }^{a^{*}}$, Vincenzo Ferri ${ }^{\mathrm{b}}$, Luca Luisellic, Giovanni Amori ${ }^{\mathrm{d}}$, \\ Giuseppe M. Carpaneto ${ }^{\mathrm{e}}$
}

\begin{abstract}
a‘Torre Flavia' LTER (Long Term Ecological Research) Station, Città Metropolitana di Roma Capitale, Protected areas - Re-

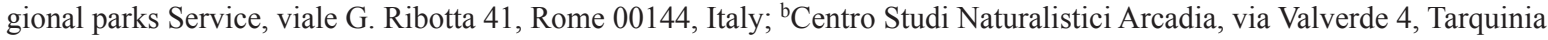
01016, Viterbo, Italy; 'IDECC-Institute for Development, Ecology, Conservation and Cooperation, Rome, Italy and Department of Applied and Environmental Biology, Rivers State University of Science and Technology, Port Harcourt, Nigeria; 'Institute of

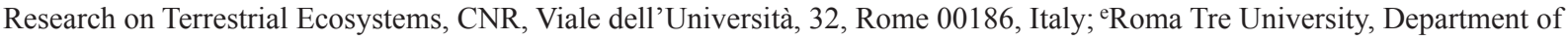
Science, Viale G. Marconi 446 00144, Rome, Italy

*Corresponding author. Email: c.battisti@cittametropolitanaroma.gov.it
\end{abstract}

\author{
Article history \\ Received: 24 January 2020; \\ accepted 28 September 2020

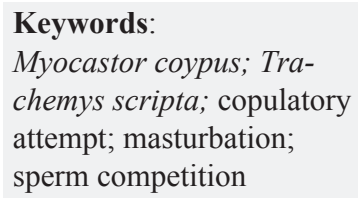

\begin{abstract}
We report the first case of sexual interaction between two phylogenetically unrelated species (coypu Myocastor coypus and pond slider Trachemys scripta, a freshwater pond turtle), both of them non-native in the study area, a remnant coastal wetland of Tyrrhenian, central Italy $\left(41^{\circ} 57^{\prime} 34.0^{\prime \prime} \mathrm{N} 12^{\circ} 02^{\prime} 58.0^{\prime \prime} \mathrm{E}\right)$. We inductively propose two different hypotheses (masturbatory act due to intense sperm competition, or behaviour induced by female pheromones) to explain this peculiar observation.
\end{abstract}

The syntopic presence of several sympatric alien species implies the emergence of new interspecific relationships among them (Amori and Battisti 2008), including newly established prey-predator relationships (e.g. Stellati et al. 2019) as well as commensalism (e.g. Calcinai et al. 2004), parasitism (e.g. Vacher et al. 2010) and even interspecific sexual interactions (e.g. Gröning and Hochkirch 2008).

In this note, we report a previously unreported case of sexual interaction between phylogenetically unrelated species (a rodent on a turtle species) from a coastal remnant wetland of central Italy where they are both non-native (Amori and Battisti 2008). In this regard, we present two hypotheses to explain this peculiar behaviour. To our knowledge, this is the first case worldwide of sexual interaction between a mammal and a reptile, both allochtonous.

\section{STUDY AREA AND BEHAVIOURAL EVI- DENCE}

On 10 October 2019 at 09.30 a.m. in the Torre Flavia wetland (Cerveteri, Ladispoli, central Italy; $41^{\circ} 57^{\prime} 34.0^{\prime \prime N}$; $12^{\circ} 02^{\prime} 58.0^{\prime \prime E}$ ), along a bank of a Phrag- mites australis reed bed, there was observed an attempt of copulatory behaviour of a coypu Myocastor coypus (Molina, 1782), a non-native rodent, on a pond slider Trachemys scripta (Schoeppf, 1792), a non-native, medium-sized, semiaquatic freshwater turtle (Ficetola et al. 2012).

This remnant coastal protected area (Special Area of Conservation under the 147/2009/CE Directive IT6030020) shows a specific, seminatural patchiness, composed of different patches of reed beds, dominated by Phragmites australis, water basins as ponds and channels used for farming of mullets (Mugil cephalus, Liza ramada, Liza saliens), rush flooded meadows dominated by Juncus sp. and Carex sp. (Juncetalia maritimi: habitat type of conservation concern; 79/409/ EEC "Habitat" Directive), and coastal dunes (Battisti 2006). In this area, a large number of anthropogenic threats have been recorded (Battisti et al. 2008, 2009); among them alien (i.e. non-native) species were widely diffused (Amori and Battisti 2008). We carried out an observation from a birdwatching hut at a distance of about $20 \mathrm{~m}$, using a Pentax photocamera.

While two pond sliders were basking on a small island, a group of coypus of different age were swimming and launching calls. Subsequently, an adult male coypu 
approached the bank occupied by a melanistic adult pond slider and slowly came up behind it. Then, the coypu began to push and scratch weakly the carapace with the nails of its front legs, but without causing the turtle to escape. After a few seconds, the coypu had a rapid erection, continuing to push and scratch weakly but without leaning his penis on the turtle. After this behaviour, the rodent slipped sideways, lifting the loins and urinating on the ground. Finally, the coypu slid into the water and swam away. On the whole, the behavioural sequence lasted about one minute and the pond slider did not show signs of intolerance nor did it react to the contact. Both turtles remained in place and continued to bask (Fig. 1a-d). In the surroundings, there were some water-related birds, i.e. Mallard (Anas platyrhynchos), Little Grebe (Tachybaptus ruficollis), and Coot (Fulica atra), all locally breeding (Causarano et al. 2009), which did not seem to give attention to the ongoing behaviour of the two animals.

\section{DISCUSSION}

Attempts of intra- and interspecific mating, copulatory behaviour and sperm competition are widely known in
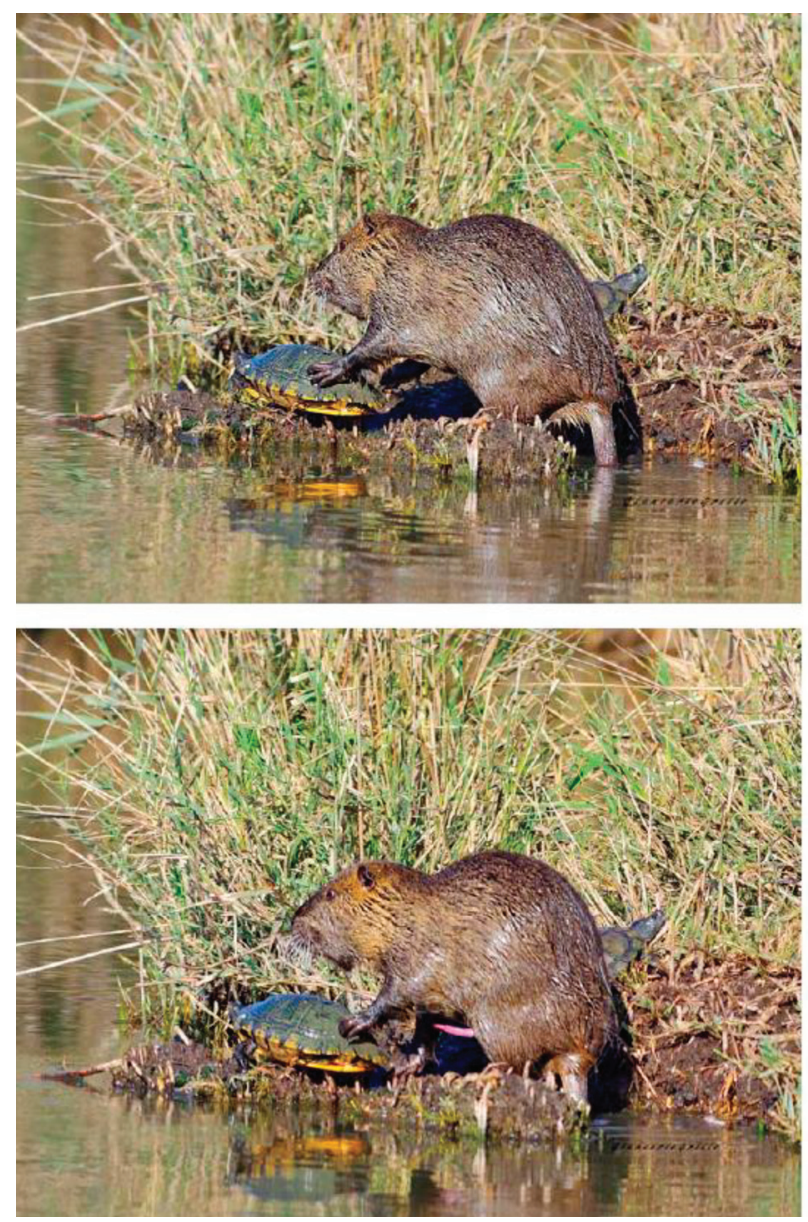

invertebrates, fish, amphibians, reptiles, and mammals, but mainly between species belonging to taxonomically close genera or families (fish: Garcia-Vazquez et al. 2001; amphibians: Orton 1951; Pearl et al. 2005; birds: Negro et al. 1992; mammals: Psarakos et al. 2003; DelBarco-Trillo et al. 2005; Herzing and Elliser 2013) either in nature or in captivity. The exceptional nature of the behaviour observed in our case consists in the fact that it is an inter-class copulatory attempt. As turtles are very far away as a sexual model for mammals, firstly we hypothesize that this behaviour could be ascribed to a masturbatory act aimed at lowering the hormonal level in males (e.g. Larsson and Beyer 1981).

Masturbatory behaviour is widely known in mammals (Tinson et al. 2000; Thomsen 2001; Waterman 2010). Generally, males under intense sperm competition may manipulate sperm quantity and quality through masturbation (which could lead to sperm waste and decrease fertility: Waterman 2010; see also Ginsberg and Huck 1989). In our case, it has been recently hypothesized that coypus occurring in the Torre Flavia remnant wetland belong to a sink population which have experienced demographic fluctuations over multiyear cycles with extinction and colonization driven by climatic extreme events, mainly linked to low winter
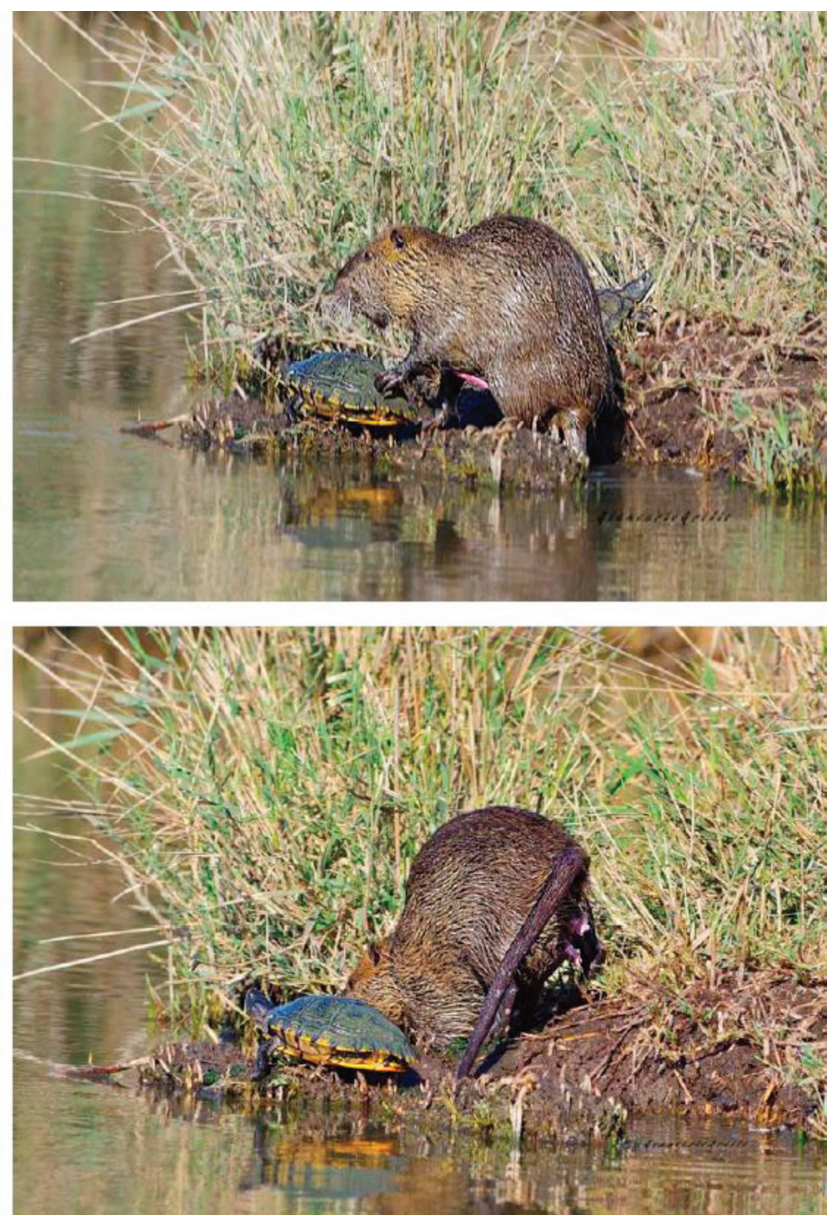

Figure $1 \mathrm{a}-\mathrm{d}$. Sequence of copulatory behaviour attempts between a coypu (Myocastor coypus) and a pond slider (Trachemys scripta) in the Torre Flavia wetland (central Italy, $\left.41^{\circ} 57^{\prime} 34.0^{\prime \prime} \mathrm{N} ; 12^{\circ} 02^{\prime} 58.0^{\prime \prime} \mathrm{E}\right)$. 
temperatures (Marini et al. 2011, 2013; Battisti et al. 2015). The last local extinctions occurred in 2012 and 2017, during heavy snowfalls, and each extinction was followed by a phase of progressive colonization (Battisti and Marini, pers. obs.). After 2017, we are witnessing a phase of demographic increase with a probable high density of adult males which may induce some of them to masturbatory behaviour. High seasonally dependent demographic fluctuations of this rodent have been evidenced by Battisti et al. (2015).

However, another hypotheses can be made. For example, a receptive coypu female might have urinated in the place where the turtle was basking; female pheromones may have stimulated the male.

In their native ranges, pond sliders are actively preyed upon by mammals (e.g. raccoons, otters, etc.; Tucker et al. 1999). On the contrary, in non-native ranges, evidence of predation on these reptiles from wild mammals is very scanty (e.g. Robey et al. 2011; for Italy: Nardone and Russo 2016) and has never been obtained for the herbivorous coypu: therefore, the absence of turtle escape during the copulatory attempt (or masturbatory act) by a coypu could be due to the fact that these reptiles do not identify these rodents as predators. Moreover, since escape behaviour is influenced by the abundance of conspecifics (Costa 2014), a high density of nonnative turtles in the Torre Flavia wetland (Battisti, pers. obs.) could be a further factor explaining the absence of escape in these animals (the first observations of these two species were in 2004; Battisti 2006).

Two projects, promoted from the public agency managing the protected area (Città metropolitana di Roma Capitale) and aimed to control the density of both species, have been planned and could start in the next future (Battisti et al. 2020).

However, further research will be necessary to test our preliminary and inductive hypotheses (see Romesburg 1981; Guthery 2007) and to verify if this peculiar behaviour is occasional or, on the contrary, recurrent in specific contexts and circumstances.

\section{ACKNOWLEDGMENTS}

Franco Andreone, Sandro Bertolino (University of Turin, Italy), Spartaco Gippoliti, Riccardo Santoro, Alessandro Zocchi, Marco Zuffi and an anonymous reviewer provided useful comments and suggestions.

\section{DISCLOSURE STATEMENT}

No potential conflict of interest was reported by the authors.

\section{ORCID: HTTP://ORCID.ORG/0000-0002- 2621-3659}

\section{REFERENCES}

Amori, G., and C. Battisti. 2008. An invaded wet ecosystem in Central Italy: an arrangement and evidence for an alien food chain. Rendiconti Lincei 19: 161-171.

Battisti, C. (Ed.), 2006. Biodiversità, gestione, conservazione di un-area umida del litorale tirrenico: la Palude di Torre Flavia [Biodiversity, management, conservation in a remnant wetland of central Italy: the Torre Flavia wetland]. Gangemi editore - Provincia di Roma, Assessorato alle politiche agricole e dell'ambiente, $496 \mathrm{pp}$.

Battisti, C., L. Luiselli, D. Pantano, and C. Teofili. 2008. On threats analysis approach applied to a Mediterranean remnant wetland: Is the assessment of human-induced threats related into different level of expertise of respondents? Biodiversity and Conservation 16: 1529-1542.

Battisti, C., L. Luiselli, and C. Teofili. 2009. Quantifying threats in a Mediterranean wetland: are there any changes in their evaluation during a training course? Biodiversity and Conservation 18: 3053-3060.

Battisti, C., F. Marini F., and L. Vignoli. 2015. A five-year cycle of coypu abundance in a remnant wetland: a case of sink population collapse? Hystrix 26: 37-40.

Battisti, C., E. De Angelis, C. Galimberti, and N. Trucchia. 2020. La gestione operativa di un ecosistema: la Palude di Torre Flavia - un manuale per studenti e volontari. Città metropolitana Roma Capitale, Roma, 224 pp.

Calcinai, B., G. Bavestrello, and C. Cerrano. 2004. Dispersal and association of two alien species in the Indonesian coral reefs: the octocoral Carijoa riisei and the demosponge Desmapsamma anchorata. Journal of the Marine Biological Association of the United Kingdom 84: 937-941.

Causarano, F., C. Battisti, and A. Sorace. 2009. Effect of winter water stress on the breeding bird assemblage of a remnant wetland in Central Italy. Revue d'Écologie (Terre Vie) 64: 61-72.

Costa, Z. J. 2014. Responses to predators differ between native and invasive freshwater turtles: environmental context and its implications for competition. Ethology 120 (7): 633-640.

DelBarco-Trillo, J., K. Gulewicz, A. Segal, M. E. McPhee, and R. E. Johnston. 2009. Can captivity lead to interspecies mating in two Mesocricetus hamster species? Journal of Zoology, London 278 (4): 308-312.

Ficetola, G. F., D. Rödder, and E. Padoa-Schioppa. 2012. Trachemys scripta (Slider terrapin). Handbook of glo- 
bal freshwater invasive species. In Earthscan, edited by Francis R., 331-339. Abingdon, UK: Taylor and Francis Group.

Garcia-Vazquez, E., P. Moran, J. L. Martinez, J. Perez, B. De Gaudemar, and E. Beall. 2001. Alternative mating strategies in Atlantic salmon and brown trout. Journal of Heredity 92 (2): 146-149.

Ginsberg, J. R., and U. W. Huck. 1989. Sperm competition in mammals. Trends in Ecology \& Evolution 4: 74-79.

Gröning, J., and A. Hochkirch. 2008. Reproductive interference between animal species. The Quarterly Review of Biology 83: 257-282.

Guthery, F. S. 2007. Deductive and inductive methods of accumulating reliable knowledge in wildlife science. Journal of Wildlife Management 71: 222-225.

Herzing, D. L., and C. R. Elliser. 2013. Directionality of sexual activities during mixed species encounters between Atlantic spotted dolphins (Stenella frontalis) and bottlenose dolphins (Tursiops truncatus). International Journal of Comparative Psychology 26: 124-134.

Larsson, K., and C. Beyer. 1981. Some aspects of the neuroendocrine regulation of mammalian sexual behaviour. In Neuroendocrine Regulation and Altered Behaviour, edited by Hrdina P. D., Singhal R. L., 95-118. Springer, Boston: MA.

Marini, F., S. Ceccobelli, and C. Battisti. 2011. Coypu (Myocastor coypus) in a Mediterranean remnant wetland: a pilot study of a yearly cycle with management implications. Wetlands Ecology and Management 19 (2):159-164.

Marini, F., E. Gabrielli, L. Montaudo, M. Vecchi, R. Santoro, C. Battisti, and G. M. Carpaneto. 2013. Diet of Coypu (Myocastor coypus) in a Mediterranean coastal wetland: a possible impact on threatened rush beds? Vie et Milieu - Life and Environments 63: 97-103.

Nardone, V., and D. Russo. 2016. Predation on nests of alien pond sliders (Trachemys scripta) by red foxes (Vulpes vulpes). X Congresso italiano di Teriologia. Abstracts.

Negro, J. J., J. A. Don zar, and F. Hiraldo. 1992. Copulatory behaviour in a colony of lesser kestrels: sperm competition and mixed reproductive strategies. Animal
Behaviour 43 (2-3): 921-930.

Orton, G. L. 1951. An example of interspecific mating in toads. Copeia 1: 78-78.

Psarakos, S., D. L. Herzing, and K. Marten. 2003. Mixedspecies associations between pantropical spotted dolphins (Stenella attenuata) and Hawaiian spinner dolphins (Stenella longirostris) off Oahu, Hawaii. Aquatic Mammals 29: 390-395.

Pearl, C. A., M. P. Hayes, R. Haycock, J. D. Engler, and J. Bowerman. 2005. Observations of interspecific amplexus between western North American rancid frogs and the introduced American bullfrog (Rana catesbeiana) and a hypothesis concerning breeding interference. American Midland Naturalist 154 (1): 126-135.

Robey, J., S. Burgin, D. Hitchen, and G. Ross. 2011. Status of an urban feral Red-Eared Slider (Trachemys scripta elegans) population in Sydney a decade on. Australian Zoologist 35 (3): 822-825.

Romesburg, H. C. 1981. Wildlife science: gaining reliable knowledge. Journal of Wildlife Management 45: 293-313.

Stellati, L., N. Borgianni, A. M. Bissattini, V. Buono, P. J. Haubrock, P. Balzani, L. Vignoli, and L. Luiselli. 2019. Living with aliens: suboptimal ecological condition in semiaquatic snakes inhabiting a hot-spot of allodiversity. Acta Oecologica 100: 103466.

Thomsen, R. 2001. Sperm competition and the function of masturbation in Japanese macaques (Macaca fuscata) (Doctoral dissertation). Available on-line: https://edoc. ub.uni-muenchen.de/105/1/Thomsen_Ruth.pdf

Tinson, A. H., K. S. Kuhad, K. Singh, and J. Al-Masri. 2000. Surgical technique to control sand masturbation in male racing camels. J. Camel. Pract. Res. 7 (2): 167-169.

Tucker, J. K., N. I. Filoramo, and F. J. Janzen. 1999. Sizebiased mortality due to predation in a nesting freshwater turtle, Trachemys scripta. American Midland Naturalist 141 (1): 198-204.

Vacher, C., J. J. Daudin, D. Piou, and M. L. Desprez-Loustau. 2010. Ecological integration of alien species into a tree-parasitic fungus network. Biological Invasions 12: 3249-3259.

Waterman, J. M. 2010. The adaptive function of masturbation in a promiscuous African ground squirrel. PLoS One 5 (9): e13060. 